\title{
Spirituality in addressing death in oncological patients in palliative care
}

\begin{abstract}
For the oncology patient in palliative care, talking about the process of death and dying can cause discomfort, because, in addition to insecurity about their future, it can awaken a negative feeling that influences the way the patient and his family deal with the situation imposed by illness. The aim of this study was to discuss the role of spirituality in coping with death in patients under palliative care. This is a descriptive, exploratory study with a qualitative approach carried out through a literature review. A search was carried out in the sources of concepts and principles: National Palliative Care Agency-ANCP and the National Cancer Institute-INCA, as well as research in Scientifc Eletronic Library Online (Scielo), in the databases, in the virtual health library (VHL) ) and Latin American in Health Sciences (LILACS) in the period from July to November 2019. One can experience spirituality even though conceptualizing it as atheism, as the search for spirituality does not necessarily mean a search for God. This demonstrates how spirituality has a particular and subjective character, without having to follow absolute truths imposed by religions. Ignoring the spiritual dimension makes the patient's approach incomplete because it puts the focus of care centered on the disease. It is concluded that the humanization of palliative care for cancer patients must go further, contemplating the patient's spiritual issues, since the concern and questions about death take on a greater proportion when physical symptoms are no longer a challenge to be addressed. overcome, but rather, the fear of the unknown before the prospect of death.
\end{abstract}

Keywords: palliative care, spirituality, oncology
Volume 12 Issue 4 - 202I

\author{
Manoel Pereira da Silva Junior, Michelly \\ de Oliveira Leopoldino, Fernanda da Silva \\ Monteiro, Ana Paula Miyazawa \\ Enfermeiro pelo Centro Universitário Tiradentes, Brazil
}

Correspondence: Manoel Pereira da Silva Junior, Enfermeiro pelo Centro Universitário Tiradentes-UNIT Maceió/AL, Brazil, Tel 55 8299| I2-II92, Email manoeljuniorftc@gmail.com

Received: August 02, 202। | Published: August 19, 202 |

\section{Initial considerations}

"Palliative care is an approach that promotes the quality of life of patients and their families, who face diseases that threaten the continuity of life, through the prevention and relief of suffering. It requires early identification, assessment and treatment of pain and other physical, psychosocial and spiritual problems" (WHO, 2002). Palliative care can be defined as a set of actions aimed at improving the quality of life of patients and families who are out of therapeutic possibilities for cure, developed by a multidisciplinary health team (ARRIEIRA et al., 2017).

The philosophy of palliative care stems from the understanding that terminal patients or those without therapeutic possibilities must have the impact of the disease minimized, through actions that reaffirm the importance of life, considering death as a natural process; establishing a care that does not accelerate the arrival of death, nor prolong it with disproportionate measures; providing relief from pain and other distressing symptoms; integrating psychological and spiritual aspects in the care strategy and offering a support system to the family so that it can face the patient's illness and survive the mourning period. ${ }^{10}$

In recent decades, among the health problems that most impacted people's quality of life, cancer was constituted as a group of diseases associated with great anxiety, anguish and stress for patients and their families. Advances related to cancer treatment are not always sufficient to achieve a cure for patients, thus, the idea of death and finitude associated with cancer patients, added to the experiences of bodily restrictions, pain and suffering, can generate questions about values and the project existential, becoming a condition that threatens roles that define the perception of oneself. ${ }^{18}$ Understanding the impact cancer has on each person's life is essential to establish care strategies.
Regardless of the prognosis, the initial diagnosis of cancer is still understood as a life-threatening event, causing, in addition to pain and physical discomfort, psychological problems that lead to reduced quality of life for patients (ARRIEIRA et al., 2017).

Although they are considered part of the natural life process of human beings, when not properly monitored, emotions can compromise the quality of life of individuals (GUIMARÃES; NOVAES; 2000). For this reason, the spiritual beliefs of each one can work as an important instrument in coping with the adversities arising from the illness process, as they provide patients and their families with an environment that offers comfort and care, in addition to fostering greater sensitivity and collaboration of all involved (ARRIEIRA et al., 2017). For cancer patients in palliative care, talking about the process of death and dying can cause discomfort, because, in addition to insecurity about their future, it can arouse a negative feeling that influences the way the patient and their family deal with the situation imposed by the disease (SANTOS, 2011). The approach to spirituality in cancer patient care can help in several aspects, including acceptance of the disease prognosis and adherence to medical decisions, especially in the most critical situations, which may be associated with better health and quality of life. (KOENIG, 2005). Given the considerations presented, this study aims to discuss the role of the spirituality of cancer patients in palliative care in coping with death. It is believed that spirituality can help cancer patients without therapeutic possibilities and family members to face the situation imposed by the disease, as well as facing death.

\section{Material and method}

This is a descriptive, exploratory study with a qualitative approach carried out through a narrative literature review. It consists of a 
discussion or the "state of the art" that deals with spirituality in facing death in cancer patients undergoing palliative care, from a theoretical or contextual point of view. Data collection was carried out from July to November 2019 and was based on sources of concepts and principles: National Palliative Care Agency-ANCP and the National Cancer Institute-INCA, as well as research in the Scientifc Electronic Library Online (Scielo ), in the databases, in the virtual health library (BVS) and in Latin American Health Sciences (LILACS). The following inclusion criteria were established: scientific articles published available between the years 2002 to 2019, in the databases: Latin American Literature in Health Sciences (LILACS) and Scientifc Electronic Library Online (Scielo). As exclusion criteria, articles that did not adhere to the proposed theme for the preparation of the work

\section{Palliative care and the death and dying process}

In 1969, a study carried out by the American psychiatrist KüblerRoss caused a great impact in the health area by presenting a reflection on the processes of denial, anger, bargaining, depression and acceptance, considered stages that people go through when they are in final stage of life. According to the author, patients who go through all the stages more easily are those encouraged to vent their anger, cry or talk about their feelings. In turn, patients who go through longer periods of denial are the ones who have the most difficulty in reaching the acceptance stage.

The finiteness of life is a difficult subject to understand and that generates many questions, since the human being is the only animal aware of its own death. Although he lives his entire existence starting and ending cycles, death is the last and only stage of the vital process that man is not prepared to face, because "he realizes how fragile he is and how vulnerable he is, thus generating a feeling of impotence, failure, guilt and sadness. ${ }^{19}$

In ancient times, some peoples worshiped death as a special event where "the dead were cared for, mummified, valued and even celebrated without fear, without the vision of failure" (FERREIRA; IGLESIAS; 2019). Nowadays, death has come to be associated with the end not only of human existence, but of its entire legacy. ${ }^{15}$ Thus, dying became an extremely complex phenomenon for human beings, although it is present throughout our lives, it seems to remain radically absent while we live (PACHECO, 2002).

Modernity and the advancement of technical-scientific knowledge brought, in the mid-twentieth century, especially in the 1970s, the valorization of the scientific aspect to the detriment of the humanistic aspect. Furthermore, death is no longer a family event, where you no longer die at home, with family members, but alone, in hospitals. In the process of medical training, the end of human life and death came to be seen, therefore, as failure, often interfering in the doctor-patientfamily relationship (FERREIRA; IGLESIAS; 2019).

In the 1990s, the emergence of alternative ways to support the patient with no prospect of cure enabled the development of palliative medicine with a focus on the quality of life of those involved, with psychological, social and spiritual assistance being considered a priority. In 2002, palliative care came to be defined as an approach that improves the quality of life of patients and families facing lifethreatening diseases, through the prevention and relief of suffering, through early identification, correct assessment and treatment of the pain and other physical, psychosocial and spiritual problems (WHO, 2002).
Although it may be present in patient care close to its finiteness, palliative care cannot be defined as the end of curative therapy, but rather the establishment of changes in the focus of treatment. The transition from active to palliative care must be a continuous process and its dynamics and time of introduction differ from patient to patient. $^{9}$

Active and palliative treatment should be associated as early as possible in the course of the disease. Developed concurrently with curative treatment, palliative care must be gradually enhanced, as a component of patient care, from diagnosis to death, in order to ensure a better quality of life. ${ }^{12}$

Despite the advances achieved in Oncology, cancer still triggers ideas of death and finitude, added to the experiences of bodily restrictions, pain and suffering, which raise questions about values and the existential project. In these moments of resignification, religiosity and spirituality can have a positive effect for the patient, on the one hand, contributing to the reduction of negative experiences caused by cancer and, on the other hand, improving their quality of life.

It is considered, therefore, that as well as physical, social and emotional pain, spiritual pain can also occur, which refers to the lack of meaning in life and death, fear of the after-death, guilt and search of faith and of spiritual comfort. The role of the family in this confrontation, in addition to impacting the way the patient goes through the stages of the disease, may or may not contribute to living with his condition (ARRIEIRA et. al. 2018).

The care that precedes grief presupposes the need to support the family through actions that value the right to information, listening, autonomy, relief from suffering, intimacy, privacy, understanding of psychosocial and spiritual aspects, and immediate care after death. ${ }^{11}$

\section{Spirituality in the face of death in the oncological patient}

Spirituality is defined as a set of deep feelings and beliefs, often religious, including a state of peace, connection to others and conceptions about the meaning and purpose of life. Spirituality, unlike religiosity, can constitute a dimension of personality, a part of the being that seeks the attribution of meanings through relationships that transcend the being itself (NATIONAL CANCER INSTITUTE, 2006).

Religion, in turn, is an instrument created by human beings to express and conceptualize spirituality, through behaviors and practices based on a particular religious denomination. ${ }^{7}$

One can experience spirituality even if conceptualizing it as atheism, as the search for spirituality does not necessarily mean a search for God. This demonstrates how spirituality has a particular and subjective character, without having to follow absolute truths imposed by religions (CAMON, 2002).

Spirituality can be understood as a complex and multidimensional part of the human experience, which includes cognitive, experiential and behavioral aspects. Cognitive aspects encompass the pursuit of meaning and purpose and truth in life, as well as the beliefs and values a person lives by. The experiential and emotional ones involve feelings of hope, love, connection, inner peace, comfort and support, that is, they reflect on the quality of the individual's internal resources, while the behavioral ones involve how people externally manifest spiritual beliefs and spiritual state internal. ${ }^{2}$ 
Some patients believe in a God who is in charge of the situation or who may have allowed such suffering for learning and strengthening. This perception can offer support and comfort to the patient, as well as reduced anxiety, increased hope or a sense of control. Religious knowledge and its practices help to regulate emotion during treatment and events that are beyond the patients' personal control (KOENIG, 2005).

The importance of spirituality for coping with the process of death and dying for the patient in palliative care can be seen in the report by Saporetti: ${ }^{20}$

I entered the dark and closed room, it was a summer afternoon and the sun was shining brightly through the cracks in the window. With his back to me, lying on a bed, a grown man mumbled something. It was the first time I visited him and according to the data that his family told me, we would have very little time together: metastatic melanoma. His story began a decade ago, when a mole became a great shadow to haunt his life: dozens of surgeries, immunotherapy, chemotherapy, etc. Today, bedridden AND without strength, he suffered from severe headaches caused by brain metastases and intracranial hypertension. According to information given by his mother and sister, he was a spiritualist, but they didn't put much emphasis on that. I approached the headboard and greeted him, a good friend of his had indicated my work.

During the clinical examination, my suspicion of such a poor prognosis became clear. He was bedridden, unable to get out of bed, hemiparetic, anasarca, anorectic and very malnourished (...) I asked him, among several things, about his religion and he replied with a simple "I have no religion". After finishing the exam he was exhausted and lay down. I watched the room, on the shelf some books on Hinduism, a small dusty Buddha statue, papers, ornaments... Suddenly an object caught my attention on the nightstand, a necklace. We usually leave objects that we are using frequently at the head of the bed, such as the medicines that were there too.

After changing the prescription, in order to alleviate the headache and improve my general condition, I went home thinking about that necklace. It seemed to me something of African origin, but I knew little about the subject and his family had no further information. His mother was Catholic and his sister was a Spiritist. They seemed at ease with their son's possible spiritual options, but they didn't seem to care about this dimension. Annoyed, I talked to a friend who practices Afro-Brazilian cults who calmly said to me:

--- This necklace must be a lagdabá.

--- One what??? - I replied more confused.

--- It's... a lagdabá, an Obaluaiê guide - he added serenely.

--- Oba-Lu... who? - I asked ironically.

She explained to me about this Orixá, who is responsible for the processes of transformation and healing, being also responsible for life and death.

I returned to his house after a few days and, to my delight, the dexamethasone and morphine regimen had worked well. She was in little pain and had gone back to eating. Care was provided by the family and a nursing assistant. The family was aware of the prognosis and, despite the pain, always remained attentive to the guidelines. Entering the room, the patient greeted me more vigorously, already sitting up in bed. When I went to examine him, I noticed the necklace around his neck and ventured:

\section{--- Sorry for the intrusion, but isn't this a lagdbá?}

He sprawled his eyes and lifting his head said,

\section{--- Do you know what this is?}

--- Not exactly... Not an Obaluaiê guide? - I asked in a joking tone.

A new perspective on that patient's care has been revealed since then. He had practiced Candomblé for decades and had moved away from its spiritual roots, even at the insistence of a doctor who had administered "alternative treatments" for some years. (...)

Over the next two weeks, his condition gradually worsened and he remained mostly asleep. So I went to visit him, as the pains had worsened, and there I witnessed a ritual dedicated to Oshun. In this tradition, each one of us is the son of one of the Orixás and returns to him at the moment of death. Oxum, the mother of fresh waters, is a female orixá, responsible for nutrition, care and fertility. My client was Oxum's son and at the end of the chants and prayers he fell asleep. Everyone left in silence and I had the feeling that he had been delivered "in his mother's arms". I guided the adjustment of medication doses and left feeling certain that he would not wake up.

Three hours passed and his wife called: "Doctor, he's gone!"

The patient with no possibility of cure requires from the team of professionals not only technical skills to perform physical care, but also the ability for emotional care based on ethics and humanization. ${ }^{19}$ Patients want to be treated as people and not as diseases, as well as to be observed and assisted in their entirety, including the physical, emotional, social and spiritual aspects (OKON, 2005).

Spirituality is an important tool for the realization of palliative care, in view of contemplating different dimensions of life, collaborating in the daily practice of health teams in diagnosing and seeking relief from phenomena such as anguish and pain. ${ }^{16}$ Negative emotions such as depression and anxiety are directly linked to the worsening of pain perception of each individual (MCWILLIAMS et al., 2004; CAMPBELL et al., 2003).

The spiritual dimension is a perspective that human beings have and that manifests itself more intensely through the expressions of beliefs, values, attitudes, behaviors and feelings when they are in a crisis situation, which requires internal resources to face them in a way that ensures comfort, tranquility, hope and a better perspective on life. ${ }^{2}$

Upon becoming aware of the proximity of death, the patient and family deal with the most varied emotions and resort to coping mechanisms, seeking to naturally rescue their spiritual dimension in an attempt to overcome and accept the situation experienced. From this understanding, the illness situation is understood as a point of mutation, through which values and attitudes are re-signified to give meaning to life. ${ }^{14}$

In the terminal phase, in which the patient has little time to live, palliative treatment becomes a priority to ensure quality of life, comfort and dignity. The key point is to bring quality of life to the patient, expressing empathy, without judgment, whenever it is necessary to listen and look in the eyes when speaking, touching to promote wellbeing, until the final moment arrives. Ignoring the spiritual dimension makes the approach to the patient incomplete, as it places the focus of care centered on the disease. 
The time of departure comes, nature reclaims the body. It must be given to the one who created it. Each people, according to their traditions, finds a way to deliver matter to nature and spirit to the Creator. Some seek the gentle course of the Waters, the body is placed on a raft or released free into the sea to meet the cradle of life, the waters of amniotic fluid. It is a plea for the spirit to find its new path and be reborn in another place, another womb here or in the immaterial. The raft departs and with it departs death. We can return to life, the deceased already has his way in the afterlife. (ANCP, 2012).

\section{Final considerations}

The ability to understand the importance of spirituality for cancer patients is a challenge to be overcome by the hegemonic hospitalcentered model installed in most services, especially in Brazil. Health teams need to develop their capabilities for truly humanized and comprehensive care, truly recognizing the patient in all its dimensions, ensuring dignity and quality of life not only for the patient, but also for their families. It is concluded that the humanization of palliative care for cancer patients should go further, contemplating the patient's spiritual issues, since the concern and questions about death take on greater proportion when physical symptoms are no longer a challenge to be overcome, but, yes, the fear of the unknown faced with the prospect of death.

\section{Acknowledgments}

None.

\section{Conflicts of interest}

Authors delcare that there is no conflict of interest.

\section{References}

1. Aquino $\mathrm{VV}$, Zago MMF. O significado das crenças religiosas para um grupo de pacientes oncológicos em reabilitação. Revista LatinoAmericana de Enfermagem. 2007;15(1):42-47.

2. Anandarajah G, Hight E. Spirituality and medical practice: using the HOPE questions as a practical tool for spiritual assessment. Am Fam Physician [Internet]. 2001;63(1):81-89.

3. Araújo JA, Leitão EMP. O cuidador de paciente sob cuidados paliativos: sobrecarga e desafios. Med HUPE-UERJ. 2012;11(2):77-81.

4. Batista DRR, Mattos M, Silva SF. Convivendo com o câncer: do diagnóstico ao tratamento. Revista de Enfermagem da UFSM. 2015;5(3):499-510.

5. Carvalho GDA, Acioly CC, Santos SR, et al. Necessidades espirituais de pacientes na terminalidade: vivência de enfermeiros assistenciais. Rev Enferm UFPE. 2014;8(4):808-813.
6. Chaar EA, Hallit S, Hajj A, et al. Evaluating the impact of spirituality on the quality of life, anxiety, and depression among patients with cancer: an observational transversal study. Supportive Care in Cancer. 2018;26(8):2581-2590.

7. Delgado-Guay MO. Spirituality and religiosity in supportive and palliative care. Current opinion in supportive and palliative care. 2014;8(3):308-313.

8. Evangelista CB, Lopes ME, Geraldo SF, et al. Espiritualidade no cuidar de pacientes em cuidados paliativos: um estudo com enfermeiros. Escola Anna Nery. 2016;20(1):176-182.

9. Gobatto CA, Araujo TCCF. Religiosidade e espiritualidade em oncologia: concepções de profissionais da saúde. Psicologia USP. 2013;24(1):11-34.

10. Hermes HR, Lamarca Isabel CA. Cuidados paliativos: uma abordagem a partir das categorias profissionais de saúde. Ciênc Saúde Coletiva. 2013;18(9):2577-2588

11. Hui D, Bruera E. Integrating palliative care into the trajectory of cancer care. Nature Reviews Clinical Oncology. 2016;13(3):159-171.

12. Instituto Nacional De Câncer, INCA. Cuidados Paliativos; 2018

13. Manual de cuidados paliativos ANCP (Academia Nacional de Cuidados Paliativos); 2012. 592 p

14. Miranda SL, Lanna MAL, Fellipe WC. Espiritualidade, depressão e qualidade de vida no enfrentamento do câncer: estudo exploratório. Psicol Cienc Prof. 2015;35(3):870-885.

15. Nogueira CC, Oliveira LM, Pimentel V. O profissional da saúde e a finitude humana a negação da morte no cotidiano profissional da assistência hospitalar. Revista virtual textos \& contextos. 2006;5(2):1-11.

16. Oliveira DS, Furtado LN, Azevedo FB, et al. Influência da espiritualidade, religiosidade e crenças pessoais na qualidade de vida de pacientes em quimioterapia. Revista Temas em Saúde. 2018;18(2):76-102.

17. Patel K, Masi D. Palliative care in the era of healthcare reform. Clinics in Geriatric Medicine. 2015;31(2):265-270.

18. Pinto C, Ribeiro JL. Avaliação da espiritualidade dos sobreviventes de cancro: implicações na qualidade de vida. Revista Portuguesa de Saúde Pública. 2010;28(1):49-56.

19. Pinto MH, Cruz MF, Cesarino CB, et al. O cuidado da enfermagem ao paciente oncológico fora de possibilidade de cura: percepção de um grupo de profissionais. Rev Cogitare. 2011;16(4):648.

20. Saporetti LA. Palliative Care: Discussing Life, Death and Dying. Chap 19, Spirituality in Palliative Care/Organizer Franklin Santana Santos São Paulo: Editora Atheneu; 2009.

21. Zimmermann C, Swami N, Monika K, et al. Early palliative care for patients with advanced cancer: a cluster-randomized controlled trial. Lancet. 2014;383(9930):1721-1730. 